\title{
Ordu ili Asarkaya Kent Ormanı ve Yoroz Kent Ormanı ile Çınarsuyu Tabiat Parkı ve Ulugöl Tabiat Parkı'nın rekreasyonel potansiyel yönünden karşılaştırılması
}

\author{
Comparison of Asarkaya Urban Forest and Yoroz Urban Forest with Çinarsuyu Nature \\ Park and Ulugöl Nature Park (Ordu province) in terms of recreational potential
}

\author{
Murat YEŞíL ${ }^{1, a}$, Mesut GÜZEL ${ }^{* 1, b}$

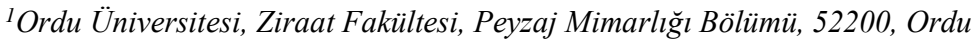

• Geliş tarihi / Received: 13.01.2021 • Düzeltilerek geliş tarihi / Received in revised form: 24.05.2021 • Kabul tarihi / Accepted: 13.06.2021

\section{$\ddot{O} z$}

Yoğun kent hayatı içerisinde doğadan kopuk, yorulan ve yıpranan insanlar ruhen ve bedenen dinlenip yenilenebilmek için zaman zaman doğa ile iç içe olma eğilimi göstermektedirler. Günümüzde tahrip olmamış doğal alanların insanlar tarafından rekreatif eylemler açısından yoğun talep görmesi bu alanların taşıdıkları kaynak değerleri ile oldukça önemli yerler olduğunu göstermektedir. Bu amaçla tabiat parkları ve kent ormanları, insanlara doğal veya yarı doğal alanlarda rekreasyon olanağı sunan tabiat parçaları olması nedeniyle yoğun bir şekilde kullanılmaktadırlar. Bu çalışma kapsamında; Ordu ilindeki bazı rekreasyon alanlarının rekreasyon potansiyeli incelenmiştir. Rekreasyon potansiyelinin belirlenmesinde, incelenen alanının rekreasyon potansiyelini yüzde olarak hesaplamaya yarayan ve pratik bir yöntem olan Gülez yöntemi esas alınmıștır. İncelenen rekreasyon alanları içerisinde; Çınarsuyu Tabiat Parkı ve Ulugöl Tabiat Parkı'nın rekreasyon potansiyeli "Yüksek", Yoroz Kent Ormanı ve Asarkaya Kent Ormanı'nın rekreasyon potansiyeli ise "Orta" olarak tespit edilmiştir. Çalışmada ikinci olarak; gerekli iyileştirmeler yapıldığı takdirde rekreasyon alanlarının mevcut potansiyellerinin ne ölçüde artacağı değerlendirilmiştir. Buna göre; bünyesinde belirlenen eksiklik ya da yetersizlikler giderildiği takdirde tüm rekreasyon alanlarının rekreasyon potansiyelinin "Yüksek" düzeyine ulaşacağı sonucuna ulaşılmıştır.

Anahtar kelimeler: Gülez yöntemi, Ordu ili, Rekreasyon, Rekreasyon potansiyeli

\begin{abstract}
In a busy urban life, tired and unhappy people who are disconnected from nature tend to be intertwined with nature from time to time to rest and regenerate spiritually and physically. The fact that the natural areas that have not been destroyed are in high demand in terms of recreational activities shows that these areas are crucial places with their resource values. Natural parks and urban forests are natural areas that offer people recreation opportunities in natural and semi-natural areas. In this study, the recreation potential of some recreation areas in Ordu province has been investigated. The Gülez method was used to determine the recreational potential. Among the recreation areas studied; The recreation potential of Çinarsuyu Nature Park and Ulugöl Nature Park has been determined as "High," and the recreation potential of Yoroz City Forest and Asarkaya City Forest has been determined as "Medium." Thus, it was evaluated to what extent the existing potentials of recreation areas would increase if necessary improvements were made. According to this, it has been concluded that the recreation potential of all recreation areas will reach the "High" level if the deficiencies identified within its structure are corrected.
\end{abstract}

Keywords: Gülez's method, Ordu province, Recreation, Recreation potential

\footnotetext{
*b Mesut GÜZEL; mesutguzel@odu.edu.tr, Tel: (0534) 410 20 94, orcid.org/0000-0001-6172-5812

${ }^{a}$ orcid.org/0000-0002-3643-5626
} 


\section{Giriş}

Genellikle insanların yaşamayı arzuladığı çevre ile kentlerin sunduğu yaşam koşulları arasında tam anlamiyla bir uyumdan söz edilememektedir. Sanayileşme, kentleşme ve kırdan kente olan hızlı nüfus hareketleri kentlerde arazi taleplerini artırmış, kentlerin yaşam kalitesini olumsuz yönde etkilemiş ve insanlarda psiko-fizyolojik dengesizliklere yol açmıştır. Bu dengeyi korumak için kişi, sessizliğe ve doğaya yakın rekreasyona gerek duymaktadır (Kurum ve Öztan, 2001). Kentlerin yoğun, stresli, hızlı, monoton ve doğadan uzak yaşam tarzı, insanlarda kısa süreliğine de olsa bulundukları yerlerden ayrılma farklı mekanlara gitme arzusunu ortaya çıkarmıştır. İnsanların doğa özlemlerini gidermek, rahatlamak ve yeni yerler keşfetmek istemesi üzerine rekreasyon etkinlikleri de artış göstermeye başlamıştır (Yeşil ve Beyli, 2018).

Rekreasyon kavram1; Latince yenilenme, yeniden yaratılma veya yeniden yapılanma anlamına gelen "recreatio" kelimesinden gelmektedir. Rekreasyon; insanların çalışma ve zorunlu ihtiyaçlar için ayırdığı zamanlar dışında yapılan, bireyin kendisini fiziksel ve zihinsel açıdan yenilemesinin yanı sira aynı zamanda zevk almasını sağlayan faaliyetlerin bütünüdür (Koç, 1991; Akten, 2003; Gültekin vd., 2013). İnsanoğlunun ruhsal ve bedensel açıdan yenilenmesini sağlayan boş zaman eylemleri, rekreasyon kavramı ile tanımlanmakta ve açıklanmaktadır (Karaküçük, 2001; Tolunay vd., 2004). McLean ve arkadaşları (2008) rekreasyonu; "Şehir, kasaba ve ilçelerdeki; eğlence alanları, parklar, oyun alanları, su merkezleri ve spor alanlarında yapılan etkinlikler" şeklinde tanımlamışlardır. Doğa temelli rekreasyon ise, doğal çevreye dayanan her türlü boş zaman etkinlikleridir (Jenkins ve Pigram, 2003) ve doğa tarafindan sağlanan önemli bir kültürel ekosistem hizmetidir (Balmford vd., 2009). Rekreasyon insanlar için evrensel bir ihtiyaçtır. Düzenli şekilde rekreasyonel aktivitelere katılan insanlar ile monoton bir hayat süren insanlar arasında sağlık düzeyi, çevreye ve yasalara uyumluluk bakımından önemli farklılıklar bulunmaktadır. Rekreasyonel aktiviteler hem insanların yaşam kalitelerini artırmakta hem de birbirleriyle ve çevreleriyle olan etkileşimini sağlıklı bir duruma getirmektedir (Sevil vd., 2012). Rekreasyona yönelik yapılan tüm tanımların ortak noktasi; rekreasyonun bireylere günlük rutin içinde kaybettikleri yaşam enerjisini yeniden kazanmaları yönünde destek olmasıdır. Dolayısıyla; çalışma hayatındaki işgücü, verimlilik ve hatta iş sağlığı ve güvenliğine kadar farklı birçok açıdan rekreasyon ve ilişkili kavramların son derece önemli olduğunu belirtmek yanlış olmayacaktır (Ayhan, 2019).

İnsana özgü bir ihtiyaç olarak rekreasyon amacıyla yapılan faaliyetler; gerçekleştirildikleri zaman dilimine ya da mekâna göre pek çok şekilde siniflandirılmaktadır (Ardahan ve Lapa, 2011). Rekreasyonun yapıldığı zamana göre yaz ve kış rekreasyonu, mekâna göre açık ve kapalı alan rekreasyonu, şekline göre aktif ve pasif rekreasyon, yere göre kentsel ve kırsal rekreasyon olarak siniflandırılabilir. Rekreasyonel alanlar; ulaşılabilirlik, kullanım şekli ve sunduğu imkanlar gibi faktörlere bağlı olarak farklı zamanlar ve zaman aralıklarında tercih görürler. Günübirlik aktiviteler için tercih edilen mekanlar kentin yoğun baskısından biraz daha uzaklaşarak kırsal alanlara doğru kaymakta ve doğal olmasının yanı sıra kente çok uzak olmayan mesafelerde yer alan bölgelerde yoğunlaşmaktadır (Yeşil ve Akbaş, 2015). Akten ve Gül (2014), "kentsel alanlara yakın doğal alanların, özellikle rekreasyonel açıdan yüksek potansiyele sahip olmasının, mevcut bitki örtüsünün ve yaban hayatının zenginliği, doğal peyzaj çeşitliliği gibi özellikleri nedeniyle kent insanı için önemli cazibe ve çekim merkezleri konumunda olduğunu" belirtmişlerdir. Çeşitli özgün peyzaj özellikleri nedeniyle çeşitli kategorilerle koruma altına alınmış kent yakın çevresindeki orman alanları da rekreasyonel amaçlı kullanımlar açısından oldukça değerli alanlardır (Ayhan, 2019). Türkiye'de 1956 tarihli 6831 sayılı Orman Kanunu ile 1983 tarihli 2873 sayılı Milli Parklar Kanunu'nun bu anlamda ayrı bir önemi vardir.

2873 sayılı Milli Parklar Kanunu'nun amac1; “milli ve milletlerarası düzeyde değerlere sahip milli park, tabiat park1, tabiat anıt1 ve tabiatı koruma alanlarının seçilip belirlenmesine, özellik ve karakterleri bozulmadan korunmasina, geliştirilmesine ve yönetilmesine ilişkin esasları düzenlemek" şeklinde tanımlanmıştır (Anonim, 2021a). Yine aynı Kanun'da doğa içerisinde rekreatif faaliyetlere olanak sağlayan tabiat parkları; "bitki örtüsü ve yaban hayatı özelliğine sahip, manzara bütünlüğü içinde halkın dinlenme ve eğlenmesine uygun tabiat parçaları" olarak ifade edilmiştir. Ayaşlıgil'e (2007) göre kent ormanı; kentlerde ya da kentlerin yakın çevresinde doğal olarak bulunan veya yapay olarak insan eliyle oluşturulmuş, kentlere sağladığı estetik ve işlevsel katkıların yanı sıra, kent insanına çok yönlü rekreatif olanaklar sunan ve kısa mesafelerde ulaşılabilen alanlardır. Yapılan tanımlardan hareketle tabiat park1 ve kent ormanının ortak 
özelliği insanlara yarı doğal-doğal alanlarda rekreasyon olanağı sunuyor olmasıdır. Türkiye, doğa temelli rekreasyon etkinlikleri bakımından oldukça zengin bir potansiyele sahiptir. 2020 yılı itibariyle Tarım ve Orman Bakanlığına bağlı Doğa Koruma ve Milli Parklar Genel Müdürlüğü bünyesinde 250 adet tabiat park1 (Anonim, 2021b) ve Orman Genel Müdürlüğü bünyesinde 134 adet kent ormanı bulunmaktadır (Anonim, 2021c).

Tabiat parkı ve kent ormanı gibi alanlarda, korunan alan mantığı ile çelişmeyen rekreasyonel aktiviteler yapılmalıdır. Bunun mümkün olabilmesi için bu türden alanların rekreasyon potansiyellerinin çıkarılması, etkin planlanması ve iyi yönetilebilmesi gerekmektedir. $\mathrm{Bu}$ anlamda, Gülez (1990) tarafindan geliştirilen rekreasyon potansiyelinin belirlenmesine yönelik geliştirilen yöntem kullanılarak yapılan birçok çalışma bulunmaktadır (Korkut ve Şimșek, 2009; Yılmaz vd., 2009; Çalık vd., 2013; Sandal ve Karademir, 2013; Altunöz vd., 2014; Türker vd., 2014; Polat ve Polat, 2016; Eröz ve Aslan 2017; Yeşi1, 2017; Yeşil ve Beyli, 2018; Yeşil ve Hacioğlu 2018; Gül ve Y1lmaz, 2019).
$\mathrm{Bu}$ çalışma ile; Ordu ilinde bulunan Çınarsuyu Tabiat Park1, Ulugöl Tabiat Park1, Yoroz Kent Ormanı ve Asarkaya Kent Ormanı'nın rekreasyon potansiyeli çıkarılmıştır. Ayrıca bu alanların rekreasyon potansiyellerinin yükseltilebileceği öngörüsüyle koruma kullanma dengesi gözetilerek bazı öneriler getirilmiştir.

\section{Materyal ve metot}

Araştırma alanı olarak Karadeniz Bölgesi'nde bulunan Ordu ili ve ildeki bazı rekreasyon alanları seçilmiştir. Ordu ili; $41^{\circ} 08^{\prime}$ ve $40^{\circ} 20^{\prime}$ kuzey enlemleri ile $36^{\circ} 40^{\prime}$ ve $38^{\circ} 06^{\prime}$ doğu boylamları arasında yer almaktadır. Doğuda Giresun ili, batıda Samsun ili, güneyde Sivas ve Tokat illeri, kuzeyde ise Karadeniz ile komşu olan Ordu ilinin yüzölçümü yaklaşı $5.952 \mathrm{~km}^{2}$ 'dir (Şekil 1). İl genel olarak Karadeniz ikliminin etkisi altındadır. Bu iklim tipinde yaz ayları nispeten serin, kışlar ise kıyı bölgelerde 1lık, yüksek rakımlarda soğuk ve karlı geçmektedir. Ayrıca her mevsim yă̆ı̧̧ gerçekleşmesi bu iklim tipinin bir diğer belirgin özelliğidir (Şensoy vd., 2008).

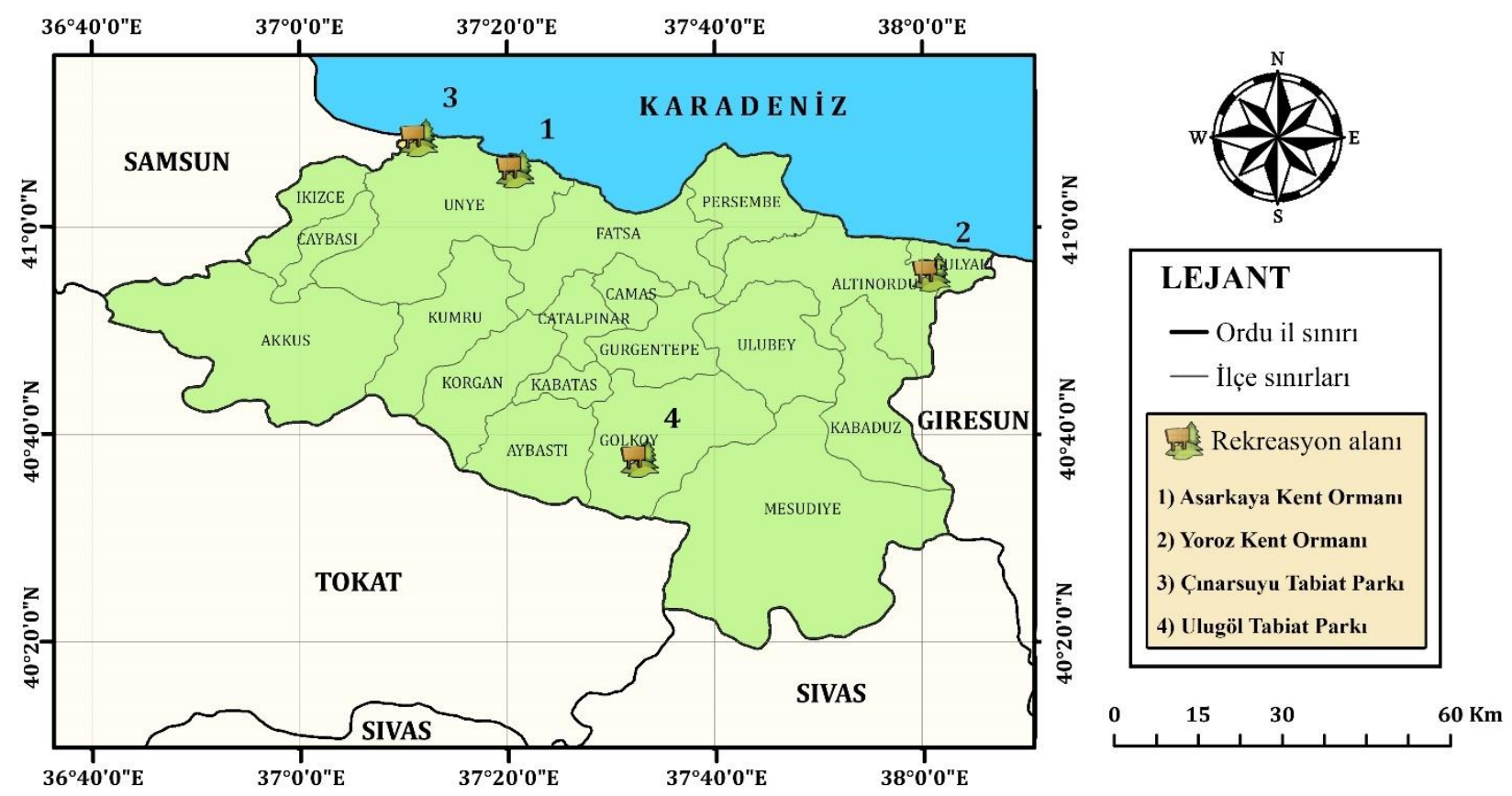

Şekil 1. Rekreasyon alanlarının konumu

Adrese Dayalı Nüfus Kayıt Sistemi verilerine göre 2019 yılı itibariyle Ordu ilinin toplam nüfusu 754.198 'dir. Halkın geçim kaynağ 1 büyük oranda meyveciliğe ve kısmen ticarete dayanmaktadır (TÜiK, 2020). Ayrıca balıkçılık, arıcılık, hayvancilık ve ormancilık da il halkının önemli geçim kaynaklarıdır. İlde gerçekleştirilen bitkisel üretimde en büyük payı, ülke üretiminin \%25'ine karşıllk gelen findık oluşturmaktadır (Anonim, 2018). Çalışmanın konusu olan Asarkaya ve Yoroz Kent Ormanı ile Çınarsuyu ve Ulugöl Tabiat Parkı'nın Ordu ili içerisindeki konumları Şekil 1'de, bu alanlar ile ilgili genel bilgiler ise Tablo 1 'de verilmiştir. 
Tablo 1. Rekreasyon alanlarına ait bilgiler (Anonim, 2021b; OGM, 2021)

\begin{tabular}{ccccc}
\hline Rekreasyon alanı & İlçe & Alan (ha) & İlan tarihi & Sit durumu \\
\hline Asarkaya Kent Ormanı (AKO) & Ünye & 44.0 & - & Yok \\
Yoroz Kent Ormanı (YKO) & Altınordu & 32.0 & - & Yok \\
Çınarsuyu Tabiat Parkı (ÇTP) & Ünye & 6.68 & 11.07 .2011 & Yok \\
Ulugöl Tabiat Parkı (UTP) & Gölköy & 26.38 & 08.09 .2009 & Yok \\
\hline
\end{tabular}

Asarkaya Kent Ormanı, Ünye ilçe merkezine 8 km ve Ordu kent merkezine $60 \mathrm{~km}$ uzaklikta, ağaçlandırılmış bir rekreasyon alanıdır. Deniz ve doğa manzarası ile dikkat çekmektedir. İçerisinde piknik alanı, et satış birimi, mangal ve semaver kiralama birimleri, mescit, lavabo gibi yapılar bulunmaktadır.

Yoroz Kent Orman1, Ordu kent merkezine yaklaşı1k $21 \mathrm{~km}$ uzaklıkta ve Saraycık Beldesi sınırları içerisinde kalmaktadır. Orman içi yürüyüş yolları ve $810 \mathrm{~m}$ rakıml zirvesi ile bilinmektedir. Alan içerisinde piknik alanı, satış ünitesi, lavabo, çeşme, orman içi yürüyüş parkuru ve seyir terası gibi fonksiyonlar yer almaktadır.

2011 yılında tescillenen Çınarsuyu Tabiat Parkı Ünye ilçesi sınırları içerisinde, Karadeniz kıyısında yer alan ve içerisinde kır lokantası, kamp alanları ve satış noktaları bulunan bir rekreasyon alanıdır. Büyüklüğü yaklaşık 6.7 ha olan tabiat park1, ziyaretçilerine piknik yapma ve denize girme olanağını birlikte sunmaktadır. Tabiat parkı Ünye İlçe merkezine $14 \mathrm{~km}$, Ordu kent merkezine ise 73 km uzaklıktadır.

2009 y1lında Tabiat Park1 olarak tescil edilen Ulugöl Tabiat Parkı, adını içerisinde yer alan krater gölünden almaktadır. Büyüklüğü 26.5 ha olan Tabiat Parkı; Gölköy İlçe merkezine 18 km, Ordu kent merkezine ise yaklaşık $80 \mathrm{~km}$ uzaklıktadır. Kasım ayının ortalarında görünür hale gelen bitkilerdeki sonbahar renk değişimini görmek amacıyla çok sayıda ziyaretçi tabiat parkına gelmektedir. Alan içerisinde konaklamaya olanak taniyan 12 adet bungalov ev yer almaktadır. Ziyaretçilerin en fazla yaptığı etkinlikler; doğa yürüyüşü, piknik, kamp ve fotoğraf çekimidir.

Rekreasyon alanlarının rekreasyon potansiyellerini belirlemede, Gülez (1990) tarafından geliştirilen "Rekreasyon Potansiyeli Değerlendirme Yöntemi" kullanılmıştır. $\mathrm{Bu}$ yöntem; bir alanın rekreasyon potansiyelini belirlemede son derece pratik olduğundan birçok çalışmada kullanılmıştır (Akten, 2003; Gülez ve Demirel, 2004; Korkut ve Şimşek, 2009; Yılmaz vd., 2009; Altunöz vd., 2014; Surat, 2017; Atabeyoğlu vd., 2017; Yeşil ve Beyli, 2018; Gül ve Yılmaz, 2019; Özçalık ve Kumru, 2019; Çetinkale Demirkan ve Sandal Erzurumlu, 2020). Yöntem ile rekreasyon potansiyeli "P + $\dot{\mathrm{I}}+\mathrm{U}+\mathrm{RK}+\mathrm{OSE}=\mathrm{RP}(\%)$ " formülü kullanılarak yüzde olarak hesaplanabilmektedir. Formülde yer alan P, peyzaj değerini; İ, iklim değerini; U, ulaşılabilirliği; RK, rekreatif kolaylıkları; OSE, olumsuz etkenleri; RP ise rekreasyonel potansiyelin yüzde olarak karşıllı̆ını ifade etmektedir (Tablo 2). Hesaplama sonucunda ortaya çıkan değer $\% 30$ 'dan az ise değerlendirilen alanın mevcut rekreasyon potansiyeli "Çok düşük", $\% 30-45$ arası ise "Düşük", \%46-60 aras1 ise "Orta", \%61-75 aras1 ise "Yüksek", \%75'den fazla ise "Çok yüksek" anlamına gelmektedir. Çalışma kapsamında incelenen tüm alanlar için RP(\%) değeri hesaplandıktan sonra gerekli iyileştirmeler yapıldığ 1 takdirde bu alanların potansiyellerinin ne düzeyde artacağ irdelenmiştir.

Rekreasyon alanlarına ait sıcaklık, yağış, güneşlenme ve rüzgârlılık gibi iklim parametreleri, alanlara en yakın meteoroloji istasyonundan sağlanmıştır. Buna göre; Yoroz Kent Ormanı iklim verileri 18527 numaralı Ordu Üniversitesi Cumhuriyet Yerleşkesi İstasyonu'ndan, Asarkaya Kent Ormanı ve Çınarsuyu Tabiat Parkı iklim verileri 17624 numaralı Ünye İstasyonu'ndan, Ulugöl Tabiat Parkı iklim verileri ise 18130 numaralı Gölköy İstasyonu'ndan elde edilmiştir. Rekreasyon alanlarının ulaşılabilirlik puanlandırmasında kullanılan mesafe ve ulaşım zamanı ölçümleri, Google Maps platformundaki "Yol Tarifi" özelliği aracılığıyla yapılmıştır. Yöntemde belirtilen "en az 100.000 nüfuslu yerleşime uzaklık" ve "en az 5.000 nüfuslu yerleşimden yaya veya taşıtla ulaşım süresi" değerleri, dört rekreasyon alanı için hesaplanmış ve yöntemde belirtilen puanlandırmada kullanılmıştır. 
Tablo 2. Rekreasyonel potansiyel puanlandırma kriterleri (Gülez, 1990)

\begin{tabular}{|c|c|c|c|}
\hline Formülde yer alan değerler & Özellikler & Açıklama & Puan \\
\hline \multirow{25}{*}{ Peyzaj Değeri (P) } & \multirow{4}{*}{ Alanın Büyüklüğü } & 10 ha.'dan büyük & 4 \\
\hline & & $5-10$ ha & 3 \\
\hline & & $1-5$ ha & 2 \\
\hline & & $0.5-1$ ha & 1 \\
\hline & \multirow{5}{*}{ Yüzeysel Durum } & Düz alan & 5 \\
\hline & & Hafif dalgalı & 4 \\
\hline & & Az meyilli & 3 \\
\hline & & Az engebeli & 2 \\
\hline & & Orta engebeli & 1 \\
\hline & \multirow{8}{*}{ Bitki Örtüsü } & Ağaçlık, çalılık, çayırlık & $7-8$ \\
\hline & & Yalnız ağaçlık, çayırlık & $6-7$ \\
\hline & & Çalılık, çayırlık, ağaçlık & $5-6$ \\
\hline & & Çayırlık, seyrek ağaçlık & $4-5$ \\
\hline & & Yalnız çalılık, çayırlık & $3-4$ \\
\hline & & Çalılık, seyrek ağaçlık & $3-4$ \\
\hline & & Çayırlık, seyrek çalılık & $2-3$ \\
\hline & & Yalnız çayırlık & $1-3$ \\
\hline & \multirow{4}{*}{ Deniz, Göl, Akarsu } & Deniz kıyısı & $7-8$ \\
\hline & & Göl kıyısı & $6-7$ \\
\hline & & Akarsu kıyısı & $4-5$ \\
\hline & & Dereler & $1-4$ \\
\hline & \multirow{3}{*}{ Görsel Kalite } & Panoramik görünümler & $3-4$ \\
\hline & & Güzel görüş ve vistalar & $2-3$ \\
\hline & & Görsel ve estetik değeri & $1-4$ \\
\hline & Diğer Özellikler & Mağara, çağlayan, tarihsel ve kültürel doku & $1-6$ \\
\hline \multirow{6}{*}{ İklim Değeri (í) } & \multirow{2}{*}{ Sicaklık } & $\begin{array}{c}\text { Yaz ayları ortalamas1 }\left({ }^{\circ} \mathrm{C}\right) \\
16-17-18-19-20-21-22-23-24-25\end{array}$ & $1-10$ \\
\hline & & $\begin{array}{c}\text { Yaz aylar1 ortalamas1 }\left({ }^{\circ} \mathrm{C}\right) \\
34-33-32-31-30-29-28-27-26-25\end{array}$ & $1-10$ \\
\hline & Yağģş & $\begin{array}{c}\text { Yaz ayları yağıs toplamı }(\mathrm{mm}) \\
50-100-150-200-250-300-350-400\end{array}$ & $8-1$ \\
\hline & Güneşlenme & $\begin{array}{c}\text { Yaz ayları bulutluluk ortalamas } \\
0-2,2-4,4-6,6-8,8-9\end{array}$ & $5-1$ \\
\hline & \multirow{2}{*}{ Rüzgârlılık } & $\begin{array}{c}\text { Yaz ayları ortalama rüzgâr hızı } \\
1 \mathrm{~m} / \mathrm{sec}^{\mathrm{d} d e n} \mathrm{az}\end{array}$ & 2 \\
\hline & & $\begin{array}{c}\text { Yaz ayları ortalama rüzgâr hızı } \\
1-3 \mathrm{~m} / \mathrm{sec} \text { aras1 }\end{array}$ & 1 \\
\hline \multirow{13}{*}{ Ulaşılabilirlik (U) } & \multirow{3}{*}{$\begin{array}{l}\text { Bölgenin Turistik } \\
\text { Önemi }\end{array}$} & Akdeniz, Ege, Marmara, Karadeniz kıyısı & $3-4$ \\
\hline & & Önemli karayolu & $2-3$ \\
\hline & & Turizmde öncelikli yöreler & $1-3$ \\
\hline & \multirow{4}{*}{$\begin{array}{c}\text { Bölgede En Az } \\
\text { 100.000 Nüfuslu Kent } \\
\text { Olması }\end{array}$} & 20 km'ye kadar & $4-5$ \\
\hline & & 50 km'ye kadar & $3-4$ \\
\hline & & 100 km'ye kadar & $2-3$ \\
\hline & & 200 km'ye kadar & $1-2$ \\
\hline & \multirow{4}{*}{$\begin{array}{c}\text { Ulaşılan Zaman } \\
\text { (en az } 5000 \text { nüfuslu } \\
\text { yerleşim biriminden) }\end{array}$} & Yürüyerek 1 saate kadar & 4 \\
\hline & & Taşıtla $0-^{1 / 2}$ saat & 3 \\
\hline & & Taşıtla $^{1 / 2}-1$ saat & 2 \\
\hline & & Taşıtla 1-2 saat & 1 \\
\hline & \multirow{2}{*}{$\begin{array}{l}\text { Ulaşım (taksi ve özel } \\
\text { oto dişında) }\end{array}$} & Yürüyerek gidilebilme & $3-4$ \\
\hline & & Taşıt bulabilme & $2-3$ \\
\hline
\end{tabular}


Belirli saatlerde taşıt bulabilme $1-3$

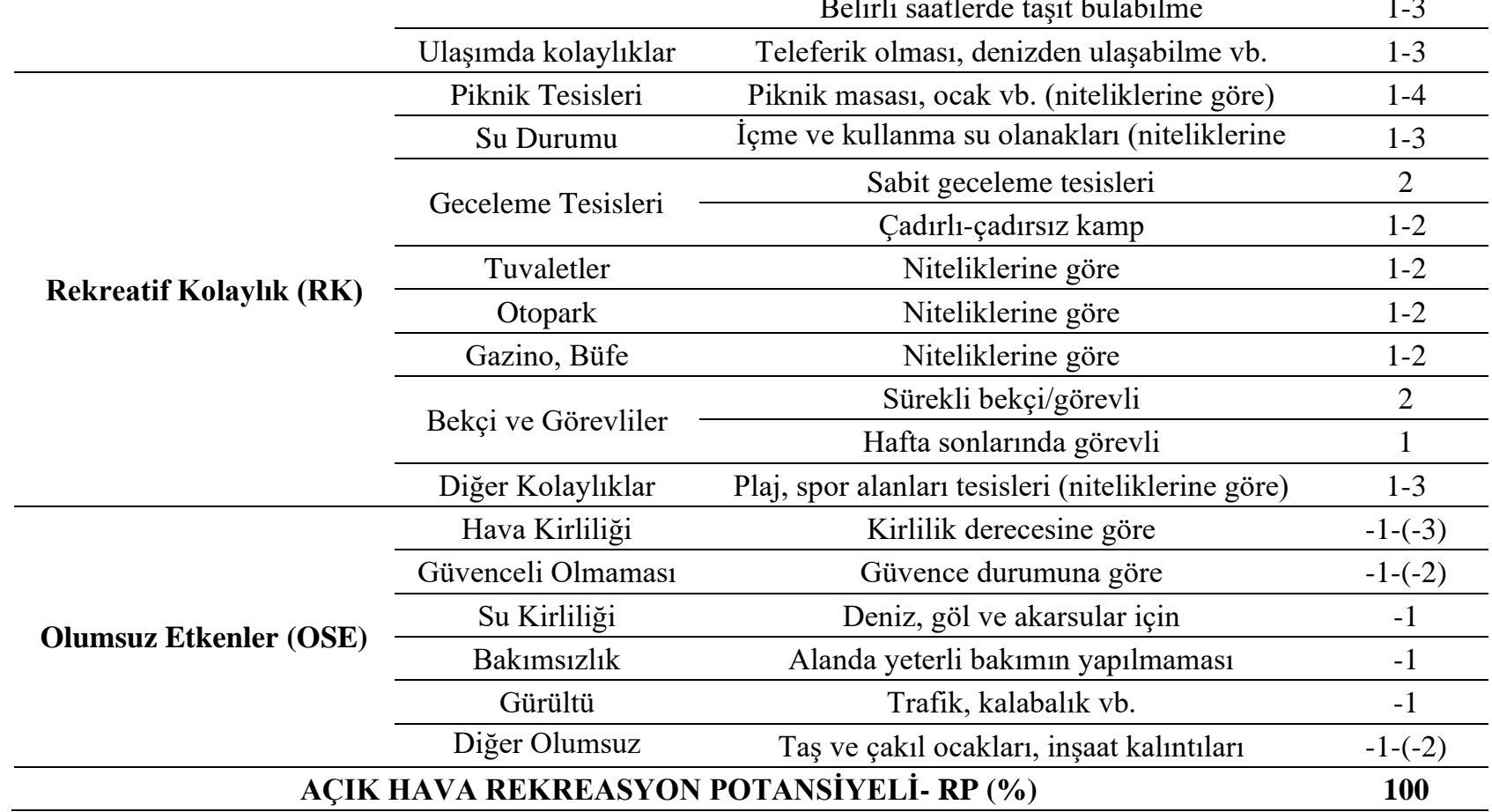

\section{Bulgular}

Rekreasyon alanlarının büyüklüğü, yüzeysel durum, bitki örtüsünün niteliği, rekreasyon alanı içerisinde su yüzeyinin bulunma durumu, alanların görsel kalite değeri gibi özelliklere göre hesaplanan peyzaj değerleri Tablo 3'te verilmiştir.

Çınarsuyu Tabiat Parkı dışındaki tüm rekreasyon alanlarının büyüklüğü, yöntemde belirtilen 10 ha'1n üzerinde olduğundan hepsine 4 puan verilmiştir. Çınarsuyu Tabiat Parkı'nın büyüklüğü 6.7 ha olduğu için 3 puan, yüzeysel duruma göre yapılan değerlendirmede topoğrafya düz ve düze yakın olduğundan 5 puan verilmiştir. Fazla engebeli olan Yoroz Kent Orman1 1 puan, "az engebeli" olan Asarkaya Kent Ormanı 2 puan ve Ulugöl Tabiat Park1 "az meyilli" sınıfına girdiğinden 3 puan almıştır. Gülez (1990) yöntemine göre bir rekreasyon alanının bitki örtüsü yönünden değerlendirilmesi ağaçlık, çalılık ve çayırlık katmanlarının bulunma durumuna göre yapılmaktadır. Bu üç katman incelenen alanda bir arada bulunuyorsa, araştırmaci 7 ya da 8 puan verebilmektedir. Örneğin alanda yalnızca çalılık ve çayırlık katmanlarının örnekleri görülüyorsa 3 ya da 4 puan verilmesi yöntemin geliştiricisi tarafindan uygun görülmüştür. $\mathrm{Bu}$ bağlamda; bitki örtüsünün katmanlılığ açısından zengin olan Yoroz Kent Ormanı ve Ulugöl Tabiat Parkı'na 8 tam puan verilirken çalılık yönünden diğer alanlara göre daha zayıf olan Çınarsuyu Tabiat Parkı'na ise 6 puan verilmiştir. Asarkaya ve Yoroz Kent Ormanı; deniz, göl, akarsu gibi su yapıları barındırmadığından bu kısımda değerlendirme dış1 tutulmuştur. Deniz kıyısında bulunan Çınarsuyu Tabiat Parkı 8 tam puan, Ulugöl Tabiat Parkı'nda göl bulunması nedeniyle de 7 puan verilmiştir.

Asarkaya ve Yoroz Kent Ormanı ile Ulugö1 Tabiat Park1 ziyaretçilere panoramik görünümler sunmaktadır. Bu sebeple bu kisımda 4 tam puan verilmiştir. Ancak Çınarsuyu Tabiat Parkı'nın görsel kalitesi diğer alanlara göre daha zayıf olduğu için 3 puan verilmiștir. Gülez yöntemine göre "mağara, çağlayan, tarihsel ve kültürel doku" gibi unsurları içeren diğer özellikler kapsamında, halk arasında çeşitli efsaneleri dolaşan Asarkaya Kent Ormanı 6 puan üzerinden 3 almıştır. Yine Ulugöl Tabiat Parkı'na da doğal ve kültürel bir değer atfedildiğinden 3 puan verilmiştir. Yoroz Kent Ormanı'na, içerisindeki çeşitli büyüklükte kayaların oluşturduğu ilginç oyuklar nedeniyle 2 puan verilmiştir. Ancak Çınarsuyu Tabiat Parkı'nda bu bağlamda puan verilebilecek bir unsur bulunmamaktadır. Tüm bu değerlendirmeler sonucunda; "Peyzaj Değeri (P)" en yüksek çıkan alan 29 puan ile Ulugöl Tabiat Parkı'dır. Bunu sırasıyla Çınarsuyu Tabiat Parkı (25 puan), Asarkaya Kent Ormanı (20 puan) ve Yoroz Kent Ormanı (19 puan) izlemektedir (Tablo 3).

Rekreasyon aktivitelerinin konforlu bir şekilde gerçekleştirilebilmesi için belirli iklim şartlarını taşıyor olması gerekmektedir. Turizm ve rekreasyon hareketliliğinin en fazla olduğu yaz aylarındaki ortalama sıcaklık ve yağış değerleri, güneşlenme süresi ve rüzgâr hızı faktörleri esas alınarak bulunan, rekreasyon alanlarının iklim değerleri puan tablosu Tablo 4'te görülmektedir. 
Tablo 3. Rekreasyon alanlarının peyzaj değerleri

\begin{tabular}{llcccc}
\hline \multirow{2}{*}{ Formüldeki değer } & Özellikler & AKO & YKO & ÇTP & UTP \\
\hline \multirow{5}{*}{ Peyzaj değeri $(P)$} & Alanın büyüklüğ̈ & 4 & 4 & 3 & 4 \\
& Yüzeysel durum & 2 & 1 & 5 & 3 \\
& Bitki örtüsü & 7 & 8 & 6 & 8 \\
& Deniz, göl, akarsu & 0 & 0 & 8 & 7 \\
& Görsel kalite & 4 & 4 & 3 & 4 \\
& Diğer özellikler & 3 & 2 & 0 & 3 \\
& Peyzaj değeri $(\boldsymbol{P})$ & $\mathbf{2 0}$ & $\mathbf{1 9}$ & $\mathbf{2 5}$ & $\mathbf{2 9}$ \\
\hline
\end{tabular}

Yoroz Kent Ormanı'na ait iklim değerlendirmesinde esas alınan Ordu Üniversitesi Cumhuriyet Yerleşkesi İstasyonu verilerine göre yaz ayları sicaklık ortalamas1 $25.5{ }^{\circ} \mathrm{C}$ 'dir (MGM, 2020). Bu yüzden 10 tam puan verilmiştir. Ünye meteoroloji istasyonuna göre yaz ayları sıcaklık ortalamas $24.4{ }^{\circ} \mathrm{C}$ düzeyinde olduğu için Asarkaya Kent Ormanı ile Çınarsuyu Tabiat Parkı'na 9 puan, Gölköy İstasyonu verilerine göre yaz ayları sicaklık ortalaması $18.9{ }^{\circ} \mathrm{C}$ derece olan Ulugöl Tabiat Parkı'na ise bu kategoride en düşük puan olan 4 puan verilmiştir. Yağış kategorisinde; yaz ayları yağış ortalaması $200 \mathrm{~mm}$ düzeyinde olan
Ulugöl Tabiat Parkı 5 puan alırken, diğer üç rekreasyon alanı yaklaşık $250 \mathrm{~mm}$ yağış ortalama değeri ile 4 puan almıştır. Dört rekreasyon alanında da yaz ayları bulutluluk ortalaması 6.4 düzeyindedir. $\mathrm{Bu}$ yüzden alanların tamamına 2 puan verilmiştir. Yine rüzgâr hızı ortalaması dört alan için de $1-3 \mathrm{~m} / \mathrm{s}$ olduğundan rüzgârlılık puanı 1 olarak belirlenmiștir. Tüm bu değerlendirmeler sonucunda; "İklim Değeri (I)" en yüksek olarak hesaplanan alan, 17 puan ile Yoroz Kent Ormanı'dır. Bunu sirasıyla Asarkaya Kent Ormanı ile Çınarsuyu Tabiat Parkı (16 puan) ve Ulugöl Tabiat Park1 (12 puan) izlemektedir (Tablo 4).

Tablo 4. Rekreasyon alanlarının iklim değerleri puan tablosu

\begin{tabular}{llcccc}
\hline Formüldeki değer & \multicolumn{1}{c}{ Özellikler } & AKO & YKO & ÇTP & UTP \\
\hline \multirow{3}{*}{ İklim değeri $(\dot{I})$} & Sicaklık & 9 & 10 & 9 & 4 \\
& Yağış & 4 & 4 & 4 & 5 \\
& Güneşlenme & 2 & 2 & 2 & 2 \\
& Rüzgârlılık & 1 & 1 & 1 & 1 \\
& İklim değeri $(\dot{I})$ & $\mathbf{1 6}$ & $\mathbf{1 7}$ & $\mathbf{1 6}$ & $\mathbf{1 2}$ \\
\hline
\end{tabular}

Bir alanın rekreasyon potansiyeli, o alana mümkün olan en kısa süre içinde ve sorunsuzca ulaş1labildiği ölçüde artmaktadır (Türker vd., 2014). Yöntemde belirtilen kriterlere göre rekreasyon alanlarının hesaplanan ulaşılabilirlik değerleri Tablo 5'te verilmiştir.

Ordu ili coğrafi konumu itibariyle deniz kıyısında yer aldığından, ildeki tüm rekreasyon alanlarına turistik önem kapsamında 4 tam puan verilmiştir. Asarkaya Kent Ormanı ve Çınarsuyu Tabiat Parkı'ndan en fazla $20 \mathrm{~km}$ mesafede, 128.101 nüfuslu (TÜIKK, 2020) Ünye İlçe merkezine ulaşılabilmektedir, bu yüzden her iki alana da 5 tam puan verilmiştir. Yoroz Kent Ormanı'ndan en yakın kent merkezi olan Altınordu'ya 20.6 km mesafede ulaşılabildiği için puanı 4 olarak belirlenmiştir. Ulugöl Tabiat Parkı'na en yakın 100.000 nüfuslu yerleşim alanı Altınordu ilçesine olan mesafe $82 \mathrm{~km}$ olduğundan 2 puan verilmiştir.
Çınarsuyu Tabiat Parkı ve Asarkaya Kent Ormanı, en az 5.000 nüfuslu yerleşime taşıtla 30 dakika içerisinde ulaşılabildiği için bu kategoriden aldıkları puan 3 olmuştur. Ulugöl Tabiat Parkı ve Yoroz Kent Ormanı'ndan en az 5.000 nüfuslu yerleşime ise 30-60 dakika arasında ulaşılmaktadır. $\mathrm{Bu}$ nedenle iki rekreasyon alanının puanı 2 olarak belirlenmiştir.

Dört rekreasyon alanı içerisinde yalnızca Çınarsuyu Tabiat Parkı'na taksi ve özel otomobil dışında bir toplu ulaşım ile gidilebilmektedir. Ancak toplu ulaşım araç saatlerinin belirli ve düzenli seferleri olmamasindan dolayı bu alana 1 puan verilirken, diğer üç rekreasyon alanı bu kategoriden puan alamamıştır. Yine ulaşımda kolaylıklar kategorisinde, Çınarsuyu Tabiat Parkı'na istenirse bireysel olarak denizden de ulaşım imkânı bulunduğundan buraya 1 puan verilirken diğer alanlara puan verilmemiştir. 
Yapılan değerlendirmeler sonucunda; "Ulaşılabilirlik Değeri (U)" en yüksek olan rekreasyon alanı, 14 puan ile Çınarsuyu Tabiat Park1 olmuştur. Bunu sırasıyla Asarkaya Kent
Ormanı (12 puan), Yoroz Kent Ormanı (10 puan) ve Ulugöl Tabiat Parkı ( 8 puan) izlemektedir (Tablo 5).

Tablo 5. Rekreasyon alanlarının ulaşılabilirlik değerleri

\begin{tabular}{|c|c|c|c|c|c|}
\hline Formüldeki değer & Özellikler & AKO & YKO & ÇTP & UTP \\
\hline \multirow{5}{*}{ Ulaşılabilirlik $(U)$} & Bölgenin turistik önemi & 4 & 4 & 4 & 4 \\
\hline & $\begin{array}{l}\text { Bölgede en az } 100.000 \text { nüfuslu kent } \\
\text { olmas1 }\end{array}$ & 5 & 4 & 5 & 2 \\
\hline & $\begin{array}{l}\text { Ulaş1lan zaman (en az } 5.000 \text { nüfuslu } \\
\text { yerleşim biriminden) }\end{array}$ & 3 & 2 & 3 & 2 \\
\hline & Ulaşım (taksi ve özel oto dışında) & 0 & 0 & 1 & 0 \\
\hline & Ulaşımda kolaylıklar & 0 & 0 & 1 & 0 \\
\hline \multicolumn{2}{|c|}{ Ulaşılabilirlik $(U)$} & 12 & 10 & 14 & 8 \\
\hline
\end{tabular}

Rekreasyon alanlarında, ziyaretçilerin; barınma, yeme-içme ve güvenlik gibi temel ihtiyaçlarını karşılayan olanakların mutlaka sunulması gerekmektedir. Bu olanakların varlığı ve niceliği kadar nitelikleri de önemlidir. $\mathrm{Bu}$ bağlamda rekreasyon alanları içerisindeki rekreatif kolaylık sağlayan tesislerin niteliklerine göre yapılan puanlandırma Tablo 6'da görülmektedir.

Gülez yöntemine göre piknik tesisleri niteliği bakımından 1 ile 4 arasında puan verilmelidir (Gülez, 1990). Piknik masalarının yeterliliği ve konumlanış1, ocak-barbekü gibi olanaklar düşünüldüğünde Yoroz Kent Ormanı dışındaki alanlara 3 puan verilmiştir. Ancak Yoroz Kent Ormanı'nda bulunan piknik masalarının yetersiz kalması, az sayıdaki piknik masasının da eski ve yıpranmış durumda olması nedeniyle 1 puan, içme ve kullanma suyu olanakları yönünden diğer üç rekreasyon alanına göre daha zayıf olan Ulugöl Tabiat Parkı'na ise 1 puan verilmiştir. Ziyaretçilerine bungalov ya da kır evi gibi sabit geceleme tesisleri ve çadırlı-çadırsız kamp olanağı sunan Çınarsuyu ve Ulugöl Tabiat Parkı'na 2 tam puan verilmiş ancak Asarkaya ve Yoroz kent ormanlarında böyle bir imkân olmadığından puan verilmemiştir. Tuvaletlerin niteliği ve temizliği yönünden dört rekreasyon alanı içerisinde en başarılısı Ulugöl Tabiat Parkı'na 2 tam puan, diğer üç alana ise 1 puan verilmiştir.

Otoparklar her iki tabiat parkında da nitelikli ve yeterli düzeyde planlanmışken, kent ormanları için bunu söylemek mümkün değildir. Özellikle kullanım yoğunluğunun arttığı dönemlerde bu alanlarda ciddi otopark sorunları ortaya çıkabilmektedir. Gazino, büfe gibi satış ve hizmet birimleri yönünden Asarkaya Kent Ormanı diğer üç alanın oldukça önündedir. Öyle ki; kent ormanı içerisinde kasap, büfe, semaver ve mangal kiralama birimi gibi çeşitli olanaklar yeterli düzeydedir. $\mathrm{Bu}$ sebeple 2 tam puan almıştır. Diğer üç rekreasyon alanında ise bu tip hizmetlerin kalitesinde ve sürekliliğinde problemler yaşanmaktadır. Ayrıca bekçi ve görevliler bulunduğundan Ulugöl ve Çınarsuyu Tabiat Parkı 2 puan alırken, kent ormanlarında görevli bulunmamaktadır. Plaj ve spor alanı gibi diğer olanaklar yönünden ilk sırada Çınarsuyu Tabiat Parkı gelmektedir. Plaj, kamp alanı, mini amfi tiyatro, kamp ateşi yakma alanı ve futbol sahası bulunmaktadır. Asarkaya Kent Ormanı'nda da çeşitli spor sahaları ve mini hayvanat bahçesi bulunmaktadır. Ancak Yoroz Kent Ormanı ve Ulugöl Tabiat Parkı diğer kolaylıklar ve olanaklar yönünden en zayıf alanlar olduklarından 1 puan verilmiştir. Tüm bu değerlendirmeler sonucunda; "Rekreatif Kolaylık Değeri (RK)" en yüksek çıkan alan, 16 puan ile Çınarsuyu Tabiat Parkı'dır. Bunu sırasıyla Ulugöl Tabiat Parkı (14 puan), Asarkaya Kent Ormanı (11 puan) ve Yoroz Kent Ormanı ( 7 puan) izlemektedir (Tablo 6).

Rekreasyon alanını doğrudan ya da dolaylı olarak etkileyen hava, su ve gürültü kirlilikleri, bakımsızlık, güven hissini zedeleyen unsurlar rekreasyon potansiyelini düşürmektedir. Rekreasyon alanlarının açık hava rekreasyon potansiyelini olumsuz yönde etkileyebilecek faktörler ve dört rekreasyon alanı için yapılan puanlandırma Tablo 7'de görülmektedir. 
Tablo 6. Rekreasyon alanlarının rekreatif kolaylık değerleri

\begin{tabular}{clcccc}
\hline Formüldeki değer & \multicolumn{1}{c}{ Özellikler } & AKO & YKO & ÇTP & UTP \\
\hline & Piknik tesisleri & 3 & 1 & 3 & 3 \\
& Su durumu & 2 & 2 & 2 & 1 \\
& Geceleme tesisleri & 0 & 0 & 2 & 2 \\
& Tuvaletler & 1 & 1 & 1 & 2 \\
Rekreatif kolaylık $(R K)$ & Otopark & 1 & 1 & 2 & 2 \\
& Gazino, büfe & 2 & 1 & 1 & 1 \\
& Bekçi ve görevliler & 0 & 0 & 2 & 2 \\
& Diğer kolaylıklar & 2 & 1 & 3 & 1 \\
& Rekreatif kolaylı $($ RK $)$ & $\mathbf{1 1}$ & $\mathbf{7}$ & $\mathbf{1 6}$ & $\mathbf{1 4}$ \\
\hline
\end{tabular}

Ulugöl Tabiat Parkı'nda işletmeden yayılan yoğun duman görüşü engellemekte ve mekândaki doğallık algısını bozmaktadır. Bu sebeple alana -1 puan verilmiştir. Diğer üç alanda böyle bir problem bulunmamaktadır. Asarkaya Kent Ormanı ve Ulugöl Tabiat Parkı'nda herhangi bir güvenlik problemi tespit edilmemiştir. Ancak Çınarsuyu Tabiat Parkı'nda başı boş dolaşan köpekler tabiat parkında güvenlik algısını düşürdüğünden (-1) puan verilmiştir. Yoroz Kent Ormanı'nda ise özellikle zirveye çıkan patika yol üzerindeki bozulmuş merdivenler ve zirvedeki çürümüş ahşap seyir platformu, güvenlik algısını oldukça düşürmektedir. Bu sebeple Yoroz Kent Ormanı (2) puan almıştır. Rekreasyon alanlarının tamamında gözle görülür düzeyde bir su kirliliği bulunmamaktadır. Ulugöl Tabiat Parkı'ndaki gölün bir bölümünde su yüzeyinin yeşil bir örtü ile kaplı olması ötrofikasyon ihtimalini akı1lara getirse de yapılan çalışmalar bunun aksini belirtmektedir (Taş vd., 2010; Taş vd., 2018).

Tabiat parklarına girişlerde ücret alınması bu alanlarda yapılacak olan bakım faaliyetleri için önemli bir kaynak oluşturduğundan kent ormanlarına göre daha avantajlı konumdadırlar. $\mathrm{Bu}$ avantajlar alanların mevcut bakımlılık durumlarına da yansımaktadır. Asarkaya ve Yoroz Kent Ormanlarında yeterli bakım olmadığından (-1) puan verilmiştir. Asarkaya Kent Ormanı ve Ulugöl Tabiat Parkı'nda insan yoğunluğundan kaynakl, Çınarsuyu Tabiat Parkı'nda ise otoyoldan kaynaklı gürültü kirliliği bulunmaktadır. Yoroz Kent Ormanı'nda ise ziyaretçileri rahatsız edecek düzeyde bir gürültü tespit edilmemiştir. İncelenen rekreasyon alanlarının hiçbirinde inşaat artığı, taş ve çakıl ocağı bulunmadığından bu anlamda diğer olumsuz etmenler kategorisinde puan kaybetmemişlerdir (Tablo 7).

Tablo 7. Rekreasyon alanlarının olumsuz etken değerleri puan tablosu

\begin{tabular}{clcccc}
\hline Formüldeki değer & \multicolumn{1}{c}{ Özellikler } & AKO & YKO & ÇTP & UTP \\
\hline & Hava kirliliği & 0 & 0 & 0 & -1 \\
& Güvenceli olmaması & 0 & -2 & -1 & 0 \\
& Su kirliliği & 0 & 0 & 0 & 0 \\
Olumsuz etkenler $(O S E)$ & Bakımsılılik & -1 & -1 & 0 & 0 \\
& Gürültü & -1 & 0 & -1 & -1 \\
& Diğer olumsuz etmenler & 0 & 0 & 0 & $-\mathbf{- 2}$ \\
\hline
\end{tabular}

Rekreasyon potansiyeli yönünden en fazla puan alan rekreasyon alanı \%69 ile Çınarsuyu Tabiat Parkı olmuştur. Bunu sırasıyla Ulugöl Tabiat Parkı (\%61), Asarkaya Kent Ormanı (\%57) ve Yoroz Kent Ormanı (\%50) takip etmektedir. İncelenen rekrasyon alanlarında koruma kullanma dengesi ve taşıma kapasitesi gözetilerek özellikle Ulaşılabilirlik, Rekreatif kolaylık ve Olumsuz etkenler başlıklarında fiziksel iyileştirmeler yapılırsa rekreasyon potansiyelleri arttırılabilir (Tablo 8). Gülez yöntemine göre; \%46-60 aras1 rekreasyon potansiyel puanı "orta", \%61-75 aras1 ise "yüksek" olarak kabul edilmektedir. Bu skalaya göre Çınarsuyu Tabiat Parkı ve Ulugöl Tabiat Parkı'nın rekreasyonel potansiyeli "yüksek", Asarkaya Kent Ormanı ve Yoroz Kent Ormanının rekreasyon potansiyeli ise "orta" düzeyde bulunmuştur. 
Tablo 8. Rekreasyon alanlarının toplam \%RP değerleri ve iyileştirmelerin yapılması durumunda alanların ulaşacağ $1 \%$ RP değerleri

\begin{tabular}{|c|c|c|c|c|c|}
\hline Formüldeki değerler & Maksimum puan & AKO & YKO & ÇTP & UTP \\
\hline Peyzaj değeri $(P)$ & 35 & 20 & 19 & 25 & 29 \\
\hline İklim değeri (i) & 25 & 16 & 17 & 16 & 12 \\
\hline Ulaşılabilirlik $(U)$ & 20 & 12 & 10 & 14 & 8 \\
\hline Rekreatif kolaylık (RK) & 20 & 11 & 7 & 16 & 14 \\
\hline Olumsuz etkenler (OSE) & $0(\min .-10)$ & -2 & -3 & -2 & -2 \\
\hline$\% R P($ Rekreasyon potansiyeli) & 100 & 57 & 50 & 69 & 61 \\
\hline İyileştirmeler yapılırsa; \%RP & 100 & 65 & 62 & 74 & 70 \\
\hline
\end{tabular}

Rekreasyon alanının lokasyonundan kaynaklanan iklimsel özellikler, alanda peyzaj değeri taşıyan unsurların dağılımı ve rekreasyon alanının yerleşim merkezlerine olan uzaklığ 1 gibi etkenler üzerinde değişiklik yapmak imkansızdır. Ancak; alan içerisinde sunulan rekreatif olanakların arttırılması, toplu taşıma gibi ulaşımda bazı kolaylıkların sağlanması, alanı etkileyen olumsuz faktörlerin bütünüyle ya da kısmen bertaraf edilmesi mümkün olabilmektedir. $\mathrm{Bu}$ tür iyileştirmelerin yapılması, rekreasyon alanlarının potansiyelini arttırarak buraları daha cazip hale getirecektir.

\section{Tartışma ve sonuçlar}

Bu çalışmada; Ordu ilindeki ikisi kent ormanı ikisi tabiat park1 olmak üzere dört önemli rekreasyon alanının Gülez (1990) tarafından geliştirilen yöntem ile mevcut rekreasyon potansiyelleri ve eksikliklerin giderilmesi durumunda alabilecekleri maksimum puanlar belirlenmiştir. $\mathrm{Bu}$ yöntem orman içi alanların rekreasyon potansiyelinin belirlenmesine yönelik geliştirilse de kolay uygulanabilirliği ve pratik kurgusu sayesinde farklı nitelikteki alanlara başarıyla uyarlanabilmiştir. Kıyı şeridi alanları (Korkut ve Şimşek, 2009; Gül ve Yilmaz, 2019), göl ve yakın çevresindeki alanlar (Surat, 2017; Bozkurt, 2019), tabiat parkları (Altunöz vd., 2014; Yeşil ve Hacioğlu, 2018; Ayhan, 2019; Özçalık ve Kumru, 2019), kent parkları (Bayramoğlu ve Yurdakul, 2019) ve köyler (Çelik vd., 2016) bu alanlardan bazılarıdır.

Ordu ilindeki bazı noktalarda açık hava rekreasyon potansiyelleri Gülez (1990) yöntemi kullanılarak hesaplanmıştır. Örneğin; Ordu ilinin önemli turizm merkezlerinden biri olan Boztepe özelinde yapılan bir araştırmada (Yeşil ve Beyli, 2018); Boztepe'nin rekreasyon potansiyeli \%77 olarak bulunmuştur. Aynı yöntem ile rekreasyon potansiyeli belirlenen bir diğer alan ise ilin ve bölgenin önemli arkeolojik merkezlerinden olan Kurul Kalesi'dir (Atabeyoğlu vd., 2017). Bu çalışma kapsamında ise; Ordu ilindeki dört önemli rekreasyon alanının potansiyel puanları aynı yöntem kullanılarak belirlenmiştir. Buna göre; Asarkaya Kent Ormanı'nın rekreasyon potansiyeli \%57, Yoroz Kent Ormanı'nın \%50, Çınarsuyu Tabiat Parkı'nın \%69 ve Ulugöl Tabiat Parkı'nın \%61 olarak bulunmuştur. Gülez (1990) yöntemine göre; bulunan değer \%46-60 aras1 ise rekreasyon potansiyeli "Orta", \%61-75 aras1 ise "Yüksek" olarak tanımlanmıştır. Buna göre; Ulugöl ve Çınarsuyu Tabiat Parkı'nın rekreasyon potansiyeli "Yüksek" olarak kabul edilirken, Yoroz ve Asarkaya Kent Ormanı'nın rekreasyon potansiyeli "Orta" düzeyde çıkmıştır.

Ordu kent merkezi ile Ulubey-Gürgentepe-Gölköy İlçeleri arasındaki güzergâhta yapımı devam eden yol çalışmaları, Ulugöl Tabiat Parkı'na ulaşımın süresini uzattığı gibi aynı zamanda yol sathındaki bozukluklar yolcu konforunu azaltmaktadır. $\mathrm{Bu}$ çalışmaların tamamlanması durumunda, özellikle kent merkezinden Ulugöl'e ulaşım daha kısa sürede ve konforlu şekilde gerçekleştirilebilecektir. Ulugöl Tabiat Parkı'nda piknik masası, barbekü, çeşme ve tezgâh gibi olanaklar, alanın popülaritesi düşünüldüğünde yetersiz kalmaktadır. $\mathrm{Bu}$ olanakların ziyaretçi talepleri ve taşıma kapasitesi düşünülerek tekrar gözden geçirilmesi gerekmektedir. Tabiat park1 içerisinde yer alan büfe ve restorandaki ürün çeşitliliğinin ve alternatif tesis sayısının arttırılması gerekmektedir. Tüm bu iyileştirmelere ek olarak; bisiklet park yeri ve farklı zorluk derecelerinde trekking parkurlarının oluşturulması durumunda, Ulugöl Tabiat Parkı'nın rekreasyon potansiyeli \%61'den \%70'e çıkacaktır. Dört rekreasyon alanı içerisinde rekreasyon potansiyeli puanını en fazla arttırabilecek alan Yoroz Kent Ormanı'dır. Buradaki tesis yetersizliği ve bakımsızlık faktörleri, rekreasyon potansiyelini önemli oranda düşürmektedir. Piknik masalarının ve zirveye çıkan patika üzerindeki ahşap merdivenlerin onarılmas1, zirvede yer alan seyir terasının yenilenerek daha güvenli hale getirilmesi, tuvalet ve çeşme olanaklarının arttırılması, restoran ve büfe hizmetinde sürekliliğinin sağlanması 
sonucunda $\% 50$ olan rekreasyon potansiyeli $\% 62$ düzeyine çıkacaktır.

Çınarsuyu Tabiat Parkı'nın rekreasyon potansiyeli \%69 çıkmıştır. Tabiat parkının bir ana yolun kenarında bulunmasından kaynaklı olarak çevresel gürültü düzeyinin yüksek olduğu belirlenmiştir. $\mathrm{Bu}$ olumsuzluk, tabiat parkının ana yol sinırında tesis edilecek perdeleyici sik bitkilendirme ile önlenebilir. Ayrıca; ulaşım olanaklarının arttırılması, özellikle yaz mevsiminde Ordu kent merkezinden ve Ünye İlçe merkezinden toplu taşıma olanağının sağlanması ile alanın rekreasyonel potansiyeli $\% 74$ düzeyine çıkarılabilir. Asarkaya Kent Ormanı, piknik tesisleri ve satış üniteleri yönünden olanakları en fazla olan rekreasyon alanıdır. Ancak; alan içerisinde geceleme tesislerinin bulunmaması, bakım eksiklikleri gibi sebepler ile potansiyeli düşük çıkmaktadır. $\mathrm{Bu}$ eksiklikler giderildiği takdirde rekreasyon potansiyeli \%65'e çıkacaktır.

Sonuç olarak; Ordu ili doğada gerçekleştirilen rekreasyonel etkinlikler yönünden önemli bir potansiyele sahiptir. Her geçen gün artan kent nüfusunun, ilerleyen yıllarda çok daha fazla rekreasyon alanına ihtiyaç duyacağı göz önünde bulundurularak planlamalar yapilmalidır. Ziyaretçilerin bir rekreasyon alanından temel beklentileri alanın ulaşılabilir olması, ulaşım araçlarında alternatifler sunulması, kaliteli ve makul fiyatlarda hizmet alınabilmesi, doğal ya da doğala yakın bir ortamın sağlanması ve temizliktir. Bununla birlikte; rekreasyon alanlarındaki aktivite ve hizmetlerin çeşitliliği de ziyaretçiler için son derece önemlidir. Söz konusu ihtiyaç ve beklentilerin ilgili kurum ve kuruluşlarca, doğa koruma ilkeleri gözetilerek karşılanması sağlıklı ve zinde bir toplum için vazgeçilmezdir. Ancak alanlara yönelik yapılacak iyileştirmeler, beraberinde ziyaretçi sayısının artması sonucunu doğuracaktır. $\mathrm{Bu}$ açıdan bakıldı̆̆ında alanların potansiyelini arttırmaya yönelik çalışmalarda mevcut durumun iyi değerlendirilmesi gerekmektedir. Doğal yapısı ile öne çıkan bu alanların doğal yapısını bozmadan, alanların özelliklerine ve kapasitelerine göre doğa dostu rekreasyonel faaliyetler planlanmalı alanların taşıma kapasitesi aşılmamalı ve doğal yapıları bozulmamalıdır.

\section{Kaynaklar}

Akten, M. (2003). Isparta ilindeki bazı rekreasyon alanlarının mevcut potansiyellerinin belirlenmesi. Türkiye Ormancllık Dergisi, 4(2), 115-132. https://doi.org/10.18182/tjf.74578
Akten, S. ve Gül, A., (2014). Korunan doğal alanlarda ziyaretçilerin olası etki düzeyleri önlem ve standartlarının belirlenmesi (Gölcük Tabiat Parkı örneği). Süleyman Demirel Üniversitesi Orman Fakültesi Dergisi, 15, 130-139. https://doi.org/10.18182/tjf.25479

Altunöz, Ö., Trrıl, A. ve Arslan Ö. E. (2014). Hamsilos Tabiat Parkı'nın rekreasyon potansiyelini belirlemeye yönelik bir araştırma. Journal of Recreation and Tourism Research, 1(1), 20-38.

Anonim (2018). Ordu ili 2017 Yll Çevre Durum Raporu. Ordu Valiliğii, Çevre ve Şehircilik İl Müdürlüğü, Ordu.

Anonim (2021a). Mevzuat Bilgi Sistemi. (2021, 11 Ocak). Erişim adresi https://www.mevzuat.gov.tr/MevzuatMetin/1.5. 2873.pdf

Anonim (2021b). Tabiat Parklarl. (2021, 11 Ocak). Erişim adresi https://www.tarimorman.gov.tr/DKMP/Menu/2 8/Tabiat-Parklari

Anonim (2021c). Resmi İstatistikler. (2021, 11 Ocak). Erişim adresi https://www.ogm.gov.tr/tr/ormanlarimiz/resmiistatistikler

Ardahan, F. ve Lapa, T. Y. (2011). Açık alan rekreasyonu: bisiklet kullanıcıları ve yürüyüşçülerin doğa sporu yapma nedenleri ve elde ettikleri faydalar. Uluslararast Insan Bilimleri Dergisi, 8(1), 1327-1341.

Atabeyoğlu, Ö., Beyli, K. N. ve Argan, A. (2017). Karadeniz'in arkeolojik hazinesi Kurul Kalesi rekreasyonel alan potansiyeli, Ordu. İnönü Üniversitesi Sanat ve Tasartm Dergisi, 7(16), 126-140. https://doi.org/10.16950/iujad.337729

Ayhan, Ç. K. (2019). Ayazmapınarı Tabiat Parkı'nın (Bayramiç, Çanakkale) rekreasyonel potansiyelinin belirlenmesi üzerine bir araştırma. Çanakkale Onsekiz Mart Üniversitesi Ziraat Fakültesi Dergisi, 7(1), 219-228. https://doi.org/10.33202/comuagri.569906

Balmford, A., Beresford, J., Green, J., Naidoo, R., Walpole, M. and Manica, A. (2009). A global perspective on trends in nature-based tourism. PLoS Biology, 7(6), 1-6. https://doi.org/10.1371/journal.pbio.1000144

Bayramoğlu, E. ve Yurdakul, N. M. (2019). Trabzon 100.Y1l Park1 peyzaj değerlerinin rekreasyon açıdan potansiyelinin saptanması. Bartın Orman Fakültesi Dergisi, 22(1), 38-46. https://doi.org/10.24011/barofd.621911

Bozkurt, S. G. (2019). Gürün (Sivas) ilçesi Gökpınar Gölü ve çevresinin rekreasyon potansiyelinin 
belirlenmesi. Türkiye Peyzaj Araştırmalarl Dergisi, 2(1), 29-39.

Çalık, F., Başer, A., Ekinci, N. M. ve Kara, T. (2013). Tabiat parklarının sportif rekreasyon potansiyeli modellemesi (Ballıkayalar Tabiat Parkı örneği). Spor Yönetimi ve Bilgi Teknolojileri Dergisi, $8(2), 35-51$.

Çelik, A., Üzümcü, T. P. ve Çetin, İ. (2016). Bursa ili Gölyazı Köyü'nün açık hava rekreasyon potansiyeli. International Journal of Social and Economic Sciences, 6(2), 32-40.

Çetinkale Demirkan, G., and Sandal Erzurumlu, G. (2020). According to method of Gülez determination of recreational potential of Niğde Atatürk City Forest. Journal of Social and Humanities Sciences Research, 7(52), 986-995. http://dx.doi.org/10.26450/jshsr.1847

Eröz, S. ve Aslan, E. (2017). Istranca (Yıldız) ormanlarının rekreasyon potansiyelinin Gülez metodu ile değerlendirilmesi. Kesit Akademi Dergisi, 9, 83-107.

Gül, S. ve Yılmaz, A. (2019). Samsun şehri kıyı şeridinin rekreasyon potansiyelinin Gülez'in açık hava rekreasyon potansiyelinin değerlendirilmesi yöntemi ile belirlenmesi. Coğrafi Bilimler Dergisi, 17(2), 318-344. https://doi.org/10.33688/aucbd.567426

Gülez, S. (1990). Orman içi rekreasyon potansiyelinin saptanması için geliştirilen bir değerlendirme yöntemi. İstanbul Üniversitesi Orman Fakültesi Dergisi, $\quad 40(2), \quad 132-147$. https://doi.org/10.17099/jffiu.92887

Gülez, S. and Demirel Ö. (2004). An evaluation method for the determination of forest recreation potential: A case study. Countryside Recreation, 12(3/4), 26-34.

Gültekin, P. G., Kaya, S. ve Müderrisoğlu, H. (2013). Düzce Üniversitesi akademik personelinin rekreatif tercihlerinin belirlenmesi. II. Rekreasyon Araştırma Kongresi. Aydın.

Jenkins, J. And Pigram, J. (2003). Encyclopedia of Leisure and Outdoor Recreation. New York, Routledge.

Karaküçük, S. (2001). Rekreasyon-Boş Zamanlarl Değerlendirme, 4. Baskı, Gazi Kitapevi, Ankara.

Koç, N. (1991). AÜZF Peyzaj Mimarlığı Bölümü Rekreasyon Ders Notları, Ankara.

Korkut, D. S. A. ve Şimşek, D. (2009). Kıyı şeridi rekreasyon potansiyelinin belirlenmesinde bir yöntem uygulaması: Tekirdağ merkez ilçe örneği. Tekirdağ Ziraat Fakültesi Dergisi, 6(3), 315-327.
Kurum, E. ve Öztan, Y. (2001). Beynam Muhafaza Ormanı ve yakın çevresinin Ankara kenti rekreasyon sistemi açısından koruma-kullanım ve planlama ilkelerinin saptanması üzerine bir araştırma. Tarım Bilimleri Dergisi, 7(1), 63-70.

Mclean, D., Hurd, D., Amy R. and Rogers, N. B. (2008). Kraus' Recreation and Leisure in Modern Society, Burlington: Jones and Bartlett Publishers.

MGM (2020). Meteoroloji Genel Müdürlüğü. https://www.mgm.gov.tr/veridegerlendirme/ilve-ilceler-istatistik.aspx $? \mathrm{k}=\mathrm{A} \& \mathrm{~m}=\mathrm{ORDU}$.

OGM (2021). Mesire Yerleri. https://www.ogm.gov.tr/tr/ormanlarimiz/mesireyerleri.

Özçalık, M. ve Kumru, S. N. (2019). Kapıçam Tabiat Parkı'nın Gülez yöntemine göre rekreasyon potansiyelinin belirlenmesi. Turkish Journal of Forest Science, 3(2), 129-141. https://doi.org/10.32328/turkjforsci.585169

Polat, S. ve Polat, S. A. (2016). Rekreasyonel tabiat parklarının korunan alanlar kapsamında incelenmesi: Mersin ili örneği. Social Sciences, 11(2), 85-115.

Sandal, E. K. ve Karademir N. (2013). Kahramanmaraş ilindeki günübirlik rekreasyon alanlarının potansiyelinin belirlenmesi ve kullanımı ile ilgili sorunlar. Türk Coğrafya Dergisi, 60, 25-36. https://doi.org/10.17211/tcd.3038

Sevil, T., Şimşek, K. Y., Katırcı, H., Çelik, O., Çeliksoy, M. A. ve Kocaekşi, S. (2012). Boş zaman ve rekreasyon yönetimi. Anadolu Üniversitesi Açıköğretim Fakültesi Yayını, Eskişehir.

Surat, H. (2017). Gülez yöntemine göre Deriner Baraj Gölü ve yakın çevresi rekreasyonel potansiyelinin değerlendirilmesi ve alan kullanım önerilerinin geliştirilmesi. Tarım ve Doğa Dergisi, 20(3), 247-257. https://doi.org/10.18016/ksudobil.289461

Şensoy, S., Demircan, M., Ulupınar, U. ve Balta, I. (2008). Türkiye iklimi, Turkish State Meteorological Service (DMI), Ankara.

Taş, B., Candan, A. Y., Can, Ö. ve Topkara, S. (2010). Ulugöl (Ordu)'ün bazı fiziko-kimyasal özellikleri. Journal of Fisheries Sciences, 4(3), 254-263.

Taş, B., Şahin, H. ve Yarılgaç, T. (2018). Ulugöl'de (Ulugöl Tabiat Parkı, Ordu) hidrofitlerin artış1 üzerine bir ön inceleme. Akademik Ziraat Dergisi, 7(1), 111-120. https://doi.org/10.29278/azd.440704 
Tolunay, A., Alkan, H. ve Korkmaz, M. (2004). Isparta Tarihi Ayazmana Mesireliği'nin açık hava rekreasyonu açısından kullanıcı özellikleri. Süleyman Demirel Üniversitesi Fen Bilimleri Enstitüsü Dergisi, 8(1), 59-70.

TÜİK, 2020. Türkiye İstatistik Kurumu. (2020, 2 Kasım). http://www.tuik.gov.tr

Türker, G. Ö., Türker, A. ve Güzel, Ö. (2014). Turistik ürün çeşitlendirmesi kapsamında Dalyan destinasyonunun rekreasyon potansiyelinin değerlendirilmesi. International Journal of Sport Culture and Science, 2(2), 70-86. https://doi.org/10.14486/IJSCS179

Uslu, Ş. ve Ayaşlıgil, T. (2007). Kent ormanlarının rekreasyonel amaçlı kullanımı ve İstanbul ili örneğinde irdelenmesi. Yıldız Teknik Üniversitesi Mimarlık Fakültesi E-Dergisi, 2(4), 213- 236.

Yeşil, M. (2017). Recreational Potential of Çambaşı Plateau of Ordu province. International Educational Applied Scientific Research Journal, 2(12), 39-42.
Yeşil, M. ve Beyli, K. N. (2018). Ordu-Boztepe'nin turizm ve rekreasyon potansiyeli ile Boztepe'nin kent imajına katkısı. Türk Tarım-Gıda Bilim ve Teknoloji Dergisi, 6(3), 291-298. https://doi.org/10.24925/turjaf.v6i3.291298.1682

Yeşil, P. and Akbaş, H., B. (2015). Determination of recreational potential of Ulugöl Nature Park. Marine Coastal Development Sustainability (MACODESU 2015), Karadeniz Technical University, Turkey.

Yeşil, P. ve Hacıoğlu, V. (2018). Limni Gölü Tabiat Parkı peyzaj değerlerinin rekreasyonel açıdan değerlendirilmesi. Türk Tarım-Gida Bilim ve Teknoloji Dergisi, 6(6), 680-688. https://doi.org/10.24925/turjaf.v6i6.680688.1568

Yılmaz, H, Karaşah, B. and Erdoğan Yüksel, E. (2009). According to the method of Gulez evaluation of the recreational potential of Kafkasör Urban Forest. Artvin Çoruh Üniversitesi Orman Fakültesi Dergisi, 10(1), 53-61. 